\title{
Quantitative inhibitory influence of porcine cumulus cells upon the maturation of pig and cattle oocytes in vitro
}

\author{
J. Petr ${ }^{1}$, L. Zetová ${ }^{2}$, J. Fulka Jr ${ }^{1}$ and F. Jílek ${ }^{1}$ \\ 1 Institute of Animal Production, 10400 Prague 10, Uhřiněves; \\ 2 Charles University, Vinicná 7, 12844 Prague 2, Czechoslovakia
}

(3rd Franco-Czechoslovak Meeting, INRA, Jouy-en-Josas, 13-14 December 1988)

Summary - Porcine cumulus oocyte complexes (COCs) were cultured together in 10- $\mu$ l droplets of culture medium. When 10 COCs were cultured for $24 \mathrm{~h}$, germinal vesicle breakdown (GVBD) occurred in $81 \%$ of them. When more COCs ( 20 or 40 ) were put into the same volume of medium the frequency of GVBD gradually decreased. This inhibition was not observed in denuded oocytes. The process of GVBD was adversely influenced when $10 \mathrm{COCs}$ were cultured in cumulus-preconditioned medium. It is concluded that porcine cumulus cells produced a factor inhibiting GVBD. After removing the inhibitory block and extensive washing, GVBD of arrested oocytes was significantly accelerated. The addition of LH or heparin only partially overcame the inhibitory action. This factor produced by porcine cumulus cells negatively influenced maturation of bovine oocytes; however, a similar effect was not demonstrated in the mouse.

Our results suggest that a high concentration of porcine cumulus cells exerts a quantitative inhibitory effect upon GVBD of porcine and cattle oocytes cultured in vitro.

oocyte - GVBD inhibition - cumulus cells - pig

Résumé - Influence inhibitrice quantitative des cellules du cumulus oophorus porcines sur la maturation in vitro d'ovocytes de truie et de vache. Des complexes ovocytes-cumuli (COC) porcins sont cultivés dans une goutte de milieu de culture de $10 \mu \mathrm{l}$. Quand $10 \mathrm{COC}$ sont cultivés ensemble pendant $24 \mathrm{~h}$, on observe la rupture de la vésicule germinative (RVG) dans $81 \%$ des ovocytes. Quand plus de $\operatorname{COC}(20$ à 40 ) sont placés dans le même volume de milieu, la fréquence de la RVG diminue graduellement. Cette inhibition n'est pas observée dans des ovocytes dénudés (sans cumulus). Le processus de RVG est inhibé quand $10 \mathrm{COC}$ sont cultivés dans du milieu préconditionné par des cumuli. La conclusion de ces travaux est que les cellules du cumulus produiraient un facteur inhibiteur de la RVG. Si l'on élève l'inhibition et si l'on procède à un lavage extensif, la RVG d'ovocytes bloqués est accélérée significativement. L'addition de $\mathrm{LH}$ ou d'héparine ne lève l'inhibition que partiellement. Le facteur inhibiteur produit par les cellules du cumulus porcin agit de la même manière sur la maturation d'ovocytes bovins, mais non sur les ovocytes murins.

Les résultats obtenus suggèrent qu'une grande concentration de cellules du cumulus porcin exerce un effet inhibiteur quantitatif sur la RVG d'ovocytes de truie et de vache cultivés in vitro.

ovocyte - rupture de vésicule germinative - inhibition - cellules du cumulus - porc 


\section{INTRODUCTION}

In vivo fully-grown oocytes resume meiosis after the LH surge. However, when competent oocytes with or without cumulus cells are cultured outside their follicle they resume meiosis spontaneously. This observation indicates that follicular cells are responsible for meiotic arrest (for review, see Thibault et al., 1987; Sato \& Koide, 1987). This idea originated in the study of Foote \& Thibault (1969), who grafted cumulus oocyte complexes (COCs) in vitro on the granulosa of immature follicles. Meiosis did not resume spontaneously under these conditions. This demonstrate that granulosa cells are responsible for the inhibition of meiosis in follicle-enclosed COCs. Many studies based on co-culture of oocytes with various follicular components were subsequently performed and further corroborated the concept of follicular inhibitory action (Tsafriri \& Channing, 1975; Dekel \& Beers, 1978, 1980; Liebfried \& First, 1980a, b; Dekel et al., 1981; Downs \& Eppig, 1984).

Similarly, numerous attempts have been made to isolate the inhibitor and determine its chemical nature. Up to date, several potential inhibitors have been described : cyclic adenosine monophosphate (CAMP), oocyte maturation inhibitor (OMI), granulosa cell factor (GCF) and lately, purine nucleotides (Sato \& Koide, 1987).

It is not known whether the cumulus cells are also the source of the oocyte maturation inhibitor(s). Since COCs are usually cultured in vitro in low $\mathrm{COC}$ : medium volume ratio, the potential inhibitor may not inhibit oocyte maturation due to its low concentration. The purpose of this study was to determine whether this potential inhibitor from porcine cumulus cells could exert an effect in a high $\mathrm{COC}$ : medium volume ratio.

\section{MATERIAL AND METHODS}

Pig oocytes were aspirated from follicles of $\approx$ 3-5 mm in diameter. Cattle oocytes were collected from follicles of $\approx 5 \mathrm{~mm}$ in diameter. Only those oocytes with compact cumuli were chosen for further experiments. Mouse oocytes were isolated from late antral follicles of sexually mature females (Baib/c) and only those containing a germinal vesicle (GV) were used.

Oocytes with compact cumuli were washed three times in medium and then cultured in 10- $\mu 1$ droplets of medium under paraffin oil at $38{ }^{\circ} \mathrm{C}$ under air with $5 \% \mathrm{CO}_{2}$. Pig oocytes were cultured for $24 \mathrm{~h}$ and those of cattle and mice for 8 or $4 \mathrm{~h}$, respectively. Preliminary studies showed that after these intervals GVBD occurred under our culture conditions. The composition of the medium was the same as described by Fulka $\mathrm{Jr}$ et al. (1986). Denuded oocytes were prepared by repeated pippetting of cumulus-enclosed oocytes through a narrow pipette and cultured in the same way.

When used, LH (bLH 13 VO5u-BIO-USDA, National Hormone and Pituitary Program, University of Maryland, USA was diluted in culture medium at a concentration of $5 \mu \mathrm{gg} / \mathrm{ml}$. Heparin (Spofa, Czechoslovakia) was used when oocytes were cultured for $24 \mathrm{~h}$ in $10 \mu \mathrm{l}$ droplets of medium containing 30,150 or $300 \mathrm{IU}$ of heparin per $\mathrm{ml}$, respectively.

At the end of culture oocytes were mounted on slides, fixed in acetic alcohol $(1: 3, \mathrm{v} / \mathrm{v})$ for at least $24 \mathrm{~h}$, stained with $1 \%$ orcein and examined under the phase contrast microscope.

The percentage of inhibition of oocytes was calculated according to the formula described by Sato and Koide (1984) :

$\%$ inhibition = (\% oocyte GVBD (control) - \% oocyte GVBD (expt.)) / \% oocyte GVBD (control).

Results were compared with the Chi-square analysis.

\section{RESULTS}

To test the effect of cumulus cells on resumption of meiosis, different numbers of 
both cumulus-enclosed and denuded porcine oocytes were cultured in 10- $\mu$ ldroplets of culture medium (Table I). When 1 , 5 , or 10 porcine COCs were cultured, germinal vesicle breakdown (GVBD) was observed in $\approx 80 \%$ of them after 24 -h culture. However, a significant inhibition of oocyte maturation was demonstrated when 20 or 40 COCs were cultured in the same volume of medium. In the former group GVBD was observed in $61 \%$ of oocytes and the latter in $20 \%$. This inhibition was not observed in denuded oocytes. The maturation of denuded oocytes was not inhibited even when 10 denuded oocytes were cocultured with $40 \mathrm{COCs}$ in the same $10 \mu \mathrm{l}$ droplet for $24 \mathrm{~h}$. These results indicated that porcine cumulus cells can quantitatively inhibit the resumption of oocyte maturation, and that their effect is mediated through the cumulus cells.

To test the reversibility of this cumulus cell inhibitory effect, $40 \mathrm{COCs}$ were cultured for $24 \mathrm{~h}$ in a $10-\mu$ droplet; the COCs were then washed and divided into 5 groups (Fig. 1). Some COCs were immediately fixed and evaluated. In this group GVDB did not exceed $20 \%$. The remaining groups were cultured separately in $10-\mu l$ droplets of fresh medium for $4,6,12$ or 24 hrs. GVDB was observed in $20,68,76$ or $85 \%$ of oocytes, respectively. Control oocytes, cultured in the same manner immediately after their aspiration from follicles underwent GVBD in $6,2,7$ or $84 \%$, respectively. This indicates that maturation in oocytes precultured under the influence of cumulus cells was significantly increased and accelerated. Indeed, $24 \mathrm{~h}$ after washing, $47 \%$ of precultured oocytes were observed in the second metaphase (M II).

$\mathrm{LH}$ was used to overcome the effect of eventual follicular inhibitors (Tsafriri, 1988). When 40 porcine COCs were cultured in $\mathrm{LH}$-enriched medium for $24 \mathrm{~h}$ the occurrence of GVBD was significantly higher than in those cultured without $\mathrm{LH}(47 \%$ vs $23 \%$ of GVBD) (Fig. 2). Significantly more $(92.9 \%)$ control oocytes resumed maturation.

Similarly heparin was used to inhibit the effect of granulosa cell factor (GCF) (Sato et al., 1986). Forty porcine COCs were cultured in a droplet of medium containing 30 , 150 or $300 \mathrm{IU}$ of heparin per $\mathrm{ml}$ for $24 \mathrm{~h}$ (Fig. 3). GVBD was observed in 12, 25 or

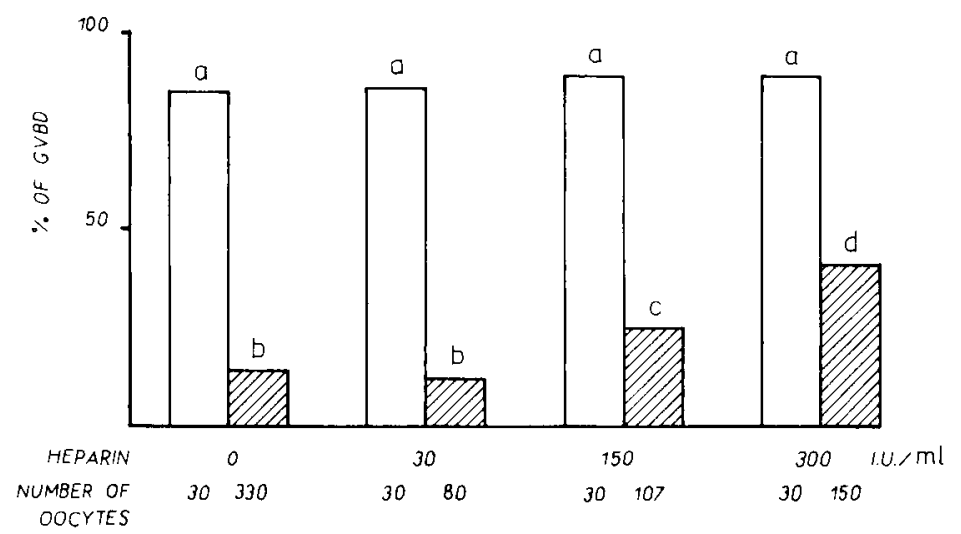

Fig. 1. The reversibility of the inhibitory activity of cumulus cells. The oocytes were either precultured for $24 \mathrm{~h}$ under the influence of the factor produced by cumulus cells (hatched columns) or cultured immediately after their aspiration from follicles (open columns). The black column represents oocytes observed in metaphase II. Statistical differences $(P<0.01)$ are indicated by different superscripts. 
Table I. The influence of cumulus cells on pig oocyte maturation.

\begin{tabular}{|c|c|c|c|c|c|c|c|}
\hline \multirow{2}{*}{$\begin{array}{l}\text { No. of oocytes } \\
\text { per droplet }\end{array}$} & \multirow{2}{*}{$\begin{array}{l}\text { Type of } \\
\text { oocytesa }\end{array}$} & \multirow{2}{*}{$\begin{array}{l}\text { No. of } \\
\text { oocytes }\end{array}$} & \multicolumn{3}{|c|}{ Stage of maturation } & \multirow{2}{*}{$\begin{array}{l}\% \text { of } \\
\text { GVBD }\end{array}$} & \multirow{2}{*}{ \% of } \\
\hline & & & GV & $G V B D$ & Undefined $b$ & & \\
\hline 1 & $\mathrm{C}_{+}$ & 60 & 7 & 50 & 3 & $87^{d}$ & 0 \\
\hline 5 & $\mathrm{C}_{+}$ & 60 & 8 & 48 & 4 & $85^{d}$ & 2 \\
\hline 10 & $\mathrm{C}+$ & 179 & 31 & 140 & 8 & $81^{d}$ & 7 \\
\hline 20 & $\mathrm{C}_{+}$ & 105 & 38 & 60 & 7 & $61^{e}$ & 29 \\
\hline 40 & $\mathrm{C}_{+}$ & 396 & 304 & 76 & 16 & $20^{f}$ & 77 \\
\hline 10 & $\mathrm{C}_{-}$ & 30 & 1 & 27 & 2 & $96^{d}$ & 0 \\
\hline 40 & $\mathrm{C}-$ & 120 & 16 & 100 & 4 & $86^{d}$ & 1 \\
\hline $10^{c}$ & $\mathrm{C}-$ & 67 & 17 & 49 & 1 & $74^{d}$ & 14 \\
\hline $40^{c}$ & $\mathrm{C}_{+}$ & 200 & 134 & 62 & 4 & 329 & 64 \\
\hline
\end{tabular}

a Oocytes were cultured with compact cumull $\left(\mathrm{C}_{+}\right)$or cumulus cells were removed mechanically before culture (C-).

b Oocytes in which the stage of maturation could not be recognized.

c Oocytes $\mathrm{C}+$ and $\mathrm{C}$ - were co-cultured together in the same droplet.

$a$ Statistical differences $(P<0.01)$ are indicated by different superscripts.

$41 \%$ of them, respectively. However, even at the highest concentration of heparin the percentage of GVBD was significantly lower than in control oocytes $(41 \%$ vs 85 of GVBD).

To test whether the potential inhibitor from cumulus cells was released into the medium, 40 porcine COCs were cultured in a $10-\mu l$ droplet for $24 \mathrm{~h}$. After this interval COCs were removed from the droplet and replaced by 10 freshly isolated porcine COCs (Table II). Only $11 \%$ of these COCs underwent GVBD $24 \mathrm{~h}$ later.
To assess whether the inhibitor was species-specific, 40 porcine COCs were cultured in 10- $\mu$ ldroplets for $24 \mathrm{~h}$. The porcine COCs were then removed and replaced by 10 freshly isolated murine or bovine COCs and cultured for 4 or $8 \mathrm{~h}$, respectively (Table II). Only $26 \%$ of bovine oocytes resumed maturation under these conditions. In control bovine oocytes a significantly higher number (69\%) of GVBD was observed. However, the maturation of the murine oocytes was not inhibited significantly and GVBD occurred in $85 \%$ of 


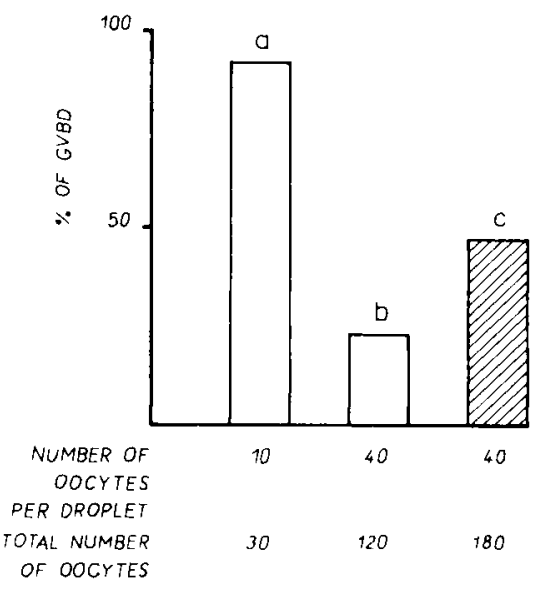

Fig. 2. The influence of $\mathrm{LH}$ upon the inhibitory activity of cumulus cells. COCs were cultured with (hatched columns) or without (open columns) 5 $\mu \mathrm{g}$ of LH per $\mathrm{ml}$. Statistical differences $(P<0.01)$ are indicated by different superscripts.

them, compared to $92 \%$ of GVBD in controls.

Based on these results it can be concluded that porcine cumulus cells release a factor able to quantitatively inhibit GVBD in porcine oocytes. The effect of this factor was fully reversible and could be partially overcome by $\mathrm{LH}$ of heparin.

It could exert its effect on bovine but not murine oocytes

\section{DISCUSSION}

The finding that oocytes removed from the follicle mature spontaneously in culture, whereas maturation of follicle-enclosed oocytes occurs only after hormonal stimulation, suggested that, within the follicle, meiosis is prevented through some follicular inhibitory action. It has been found that granulosa cells in contact with cultured oocytes suppress spontanous maturation (Tsafriri \& Channing, 1975; Eppig \& Downs, 1984; Anderson et al., 1985). These studies indicated that granulosa cells produce factors that sustain meiotic arrest.

Table II. The species specificity of inhibitory activity from cumulus cells.

\begin{tabular}{|c|c|c|c|c|c|c|c|c|}
\hline \multirow[t]{2}{*}{ Species } & \multirow{2}{*}{$\begin{array}{l}\text { Time of } \\
\text { culture }\end{array}$} & \multirow{2}{*}{$\begin{array}{l}\text { Type of } \\
\text { culture a }\end{array}$} & \multirow{2}{*}{$\begin{array}{c}\text { No. of } \\
\text { oocytes }\end{array}$} & \multicolumn{3}{|c|}{ Stage of maturation } & \multirow{2}{*}{$\begin{array}{l}\% \text { of } \\
\text { GVBD }\end{array}$} & \multirow{2}{*}{$\begin{array}{c}\% \text { of } \\
\text { inhibition }\end{array}$} \\
\hline & & & & GV & $G V B D$ & Undefined $b$ & & \\
\hline \multirow[t]{2}{*}{ Pig } & 24 & control & 40 & 4 & 34 & 2 & $89 c$ & 0 \\
\hline & & $x$ & 79 & 65 & 8 & 6 & $11^{d}$ & 88 \\
\hline \multirow[t]{2}{*}{ Cattle } & 8 & control & 42 & 13 & 29 & 0 & $69^{c}$ & 0 \\
\hline & & $x$ & 61 & 45 & 16 & 0 & $26^{d}$ & 62 \\
\hline \multirow[t]{2}{*}{ Mouse } & 4 & control & 72 & 6 & 66 & 0 & 92 & 0 \\
\hline & & $x$ & 60 & 9 & 51 & 0 & 85 & 8 \\
\hline
\end{tabular}

a Ten bovine and murine oocytes were cultured in $10 \mu \mathrm{l}$ of fresh medium (control) or in $10 \mu \mathrm{l}$ fo medium where 40 procine COCs were cultured previously for $24 \mathrm{~h}(\mathrm{X})$, respectively.

$b$ Oocytes in which the stage of maturation could not be recognized.

c, d Statistical differences within species $(P<0.01)$ are indicated by different superscripts. 


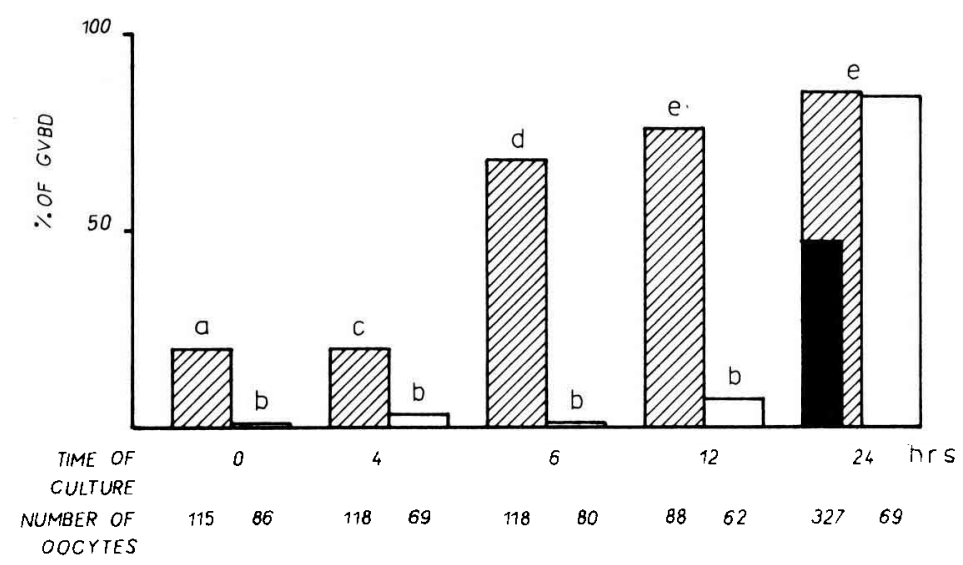

Fig. 3. The influence of heparin upon the inhibitory activity of cumulus cells. Ten (open columns) or 40 (hatched columns) COCs were cultured per droplet. Statistical differences $(P<0.025)$ are indicated by different superscripts.

We report that pig oocytes do not resume meiosis spontaneously when COC : medium volume ratio is increased by culturing more than $10 \mathrm{COCs}$ in a $10-\mu$ droplet of medium. One possible explanation is that the $\mathrm{pH}$ of culture medium could influence maturation. Sato \& Koide (1987) demonstrated in porcine oocytes that at $\mathrm{pH} 6.8-7.0$ the time required to progress to the second metaphase was delayed by several hours compared to $\mathrm{pH} 7.2-7.4$. However, such $\mathrm{pH}$ decrease was not observed in our culture conditions, so that other factor(s) must be involved. The maturation of denuded oocytes was not inhibited by an increasing oocyte : medium volume ratio, even when they were cultured in an environment where COC : medium volume ratio was high enough to inhibit resumption of meiosis in intact oocytes. It is therefore unlikely that exhaustion of some nutritional components in the medium caused the inhibition. These data support the idea that porcine cumulus cells produce at least one factor inhibiting oocyte maturation. They further suggest that this factor exerts its inhibitory action not directly on oocytes, but through the mediation of cumulus cells. This agrees with the observation that cumulus cells are required for the inhibitory action of oocyte maturation inhibitor (OMI) in pig (Hillensjö et al., 1979) and rat oocytes (Tsafriri \& Bar-Ami, 1982). In contrast, an inhibitory fraction of human follicular fluid prevented maturation of denuded rat oocytes (Chari et al., 1983), and the low molecular weight fraction of porcine follicular fluid inhibited the maturation of mouse cumulus-free ova (Downs \& Eppig, 1984).

The inhibition of GVDB was reversible. After thorough washing in the medium, the subsequent culture in lower COC : medium volume ratio led to the GVBD after $6 \mathrm{~h}$. This means that oocytes released from the influence of cumulus cell factor completed GVBD much faster that oocytes freshly isolated from the follicle (Motlik and Fulka, 1976; and the present result). This acceler- 
ation could not be due to the delayed onset of GVBD occuring under the influence of the cumulus cell factor, because GVBD was not observed and GVs remained intact, even in 40 COCs cultured for $48 \mathrm{~h}$ in a 10- $\mu$ droplet (data not shown). It therefore appears that the inhibitory factor from porcine cumulus cells did not prevent all events involved in GVBD and only represents a part of the inhibitory influence that is exerted on the oocyte by the somatic components of the follicle. In this connection, a similar acceleration of maturation was observed after the washing away of cycloheximide, a protein synthesis inhibitor, in sheep (Moor \& Crosby, 1986) and pig oocytes (Kubelka et al., 1988).

$\mathrm{LH}$ induces resumption of meiosis in vivo or within the follicle-enclosed oocytes in vitro. In addition, $\mathrm{LH}$ has been reported to alleviate the inhibitory action of porcine follicular fluid or of its purified fractions (Tsafriri \& Channing, 1975), of bovine or hamster follicular fluid (Gwatkin \& Andersen, 1976), of rat granulosa cell conditioned medium, as well as that of cocultured with rat granulosa cells (Tsafriri et al., 1977). Hence the ability of LH to partly overcome the inhibition of meiosis by a cumulus cell factor described in the present study lends support to the view that this factor may have a physiological role in the regulation of meiosis.

$\mathrm{LH}$ is known to stimulate the preovulatory follicle to produce glycosaminoglycans which accumulate on the surface and in the intercellular spaces of the cumulus cells (Eppig, 1979). Sato et al. (1986) have demonstrated that among the glycosaminoglycans, heparin and heparan sulfate interact with the GCF and nullify its maturation inhibitory activity. Based on their experimental results, Sato \& Koide (1987) have proposed the hypothesis that glycosaminoglycans can prevent the action of GCF on the oocyte by binding the factor. In this manner oocytes are supposed to be protected from the arresting influence of the maturation inhibitory factor and to resume meiosis. In the present study it is shown that heparin at least partly blocked the activity of cumulus cell factor. It is thus possible that glycosaminoglycans could be involved in the blocking of cumulus cell factor during gonadotropin-induced resumption of maturation.

It is generally accepted that the inhibitory effect of OMI is not species-specific. Thus human follicular fluid inhibits the maturation of pig (Hillensjö et al., 1978), rat (Hillensjö et al., 1981) and Xeponus oocytes (Pomerantz \& Bilello, 1987); bovine follicular fluid inhibits hamster oocyte maturation (Gwatkin and Andersen, 1976). Under our conditions the inhibitory factor from porcine cumulus cells does not inhibit maturation in mouse oocytes but it is able to exert its effect on cattle oocytes.

The quantitative inhibiton and its incomplete reversibility by LH or heparin may be perhaps related to the nonhomogeneity of the oocyte population aspirated from ovaries (Homa et al., 1988), the impurity of substances, or to culture conditions employed. Another explanation for quantitative inhibition is the interaction of inhibitory factor(s) and maturation-inducing factor(s). Such factors produced by granulosa cells were proposed by Byskov (1979) and detected by use of bioassay in mouse (Byskov, 1974), hamster (Fayer et al., 1979) and human (Yding Andersen et al., 1981). Recently, substances promoting cytoplasmic development of pig follicular oocytes were demonstrated in porcine follicular fluid (Naito et al., 1988) and pig follicular tissue was reported to produce similar factors (Mattiolli et al., 1988a, b).

Our data strongly suggest that pig cumulus cells produce factor(s) quantitatively inhibiting oocyte maturation, but its biochemical nature has yet to be determined. 


\section{ACKNOWLEDGMENTS}

We would like to express out utmost gratitude to the National Hormone and Pituitary Program, University of Maryland, USA for supplying LH.

\section{REFERENCES}

Anderson L.D., Stone S.L. \& Channing C.P. (1985) Influence of hormones on the inhibitory activity of oocyte maturation present in conditioned media of porcine granulosa cells. Gamete Res. 12, 119-130

Byskov A.G. (1979) Regulation of meiosis in mammals. Ann. Biol. Anim. Biochim. Biophys. $19,1251-61$

Byskov A.G. (1974) Does rete ovarii act as a trigger for the onset of meiosis ? Nature 252, 396-397

Chari S., Hillensjö T., Magnusson C. \& Daume E. (1983) In vitro inhibition of rat oocyte meiosis by human follicular fluid fractions. Arch. Gynecol. 233, 155-165

Dekel N. \& Beers W.H. (1978) Rat oocyte maturation in vitro: relief of cyclic AMP inhibition by gonadotropins. Proc. Natl. Acad. Sci. USA 75, 3469-3473

Dekel N. \& Beers W.H. (1980) Development of rat oocyte in vitro : inhibition and induction of maturation in the presence or absence of the cumulus oophorus. Dev. Biol. 75, 247-252

Dekel N., Lawrence T.S., Gilula N.B. \& Beers W.H. (1981) Modulation of cell-to-cell communication in the cumulus-oocyte complex and the regulation of oocyte maturation by LH. Dev. Biol. 86, 356-362

Downs S.M. \& Eppig J.J. (1984) Cyclic adenosine monophosphate and ovarian follicular fluid act synergistically to inhibit mouse oocyte maturation. Endocrinology 114, 418-427

Eppig J.J. (1979) A comparison between growth in co-culture with granulosa cells and oocytes with granulosa cell-oocyte junctional contact maintained in vitro. J. Exp. Zool. 209, 345-353

Eppig J.J. \& Downs S.M. (1984) Chemical signals that regulate mammalian oocyte maturation. Biol. Reprod. 30, 1-11
Fayer A.B., Schneider J.A., McCall D., Ances I.G. \& Polakis S.E. (1979) The induction of meiosis by ovaries of newborn hamsters and its relation to the action of the extraovarian structures in mesovarium (rete ovarii). Ann. Biol. Anim. Biochim. Biophys. 19, 1273-1278

Foote W.D. \& Thibault C. (1969) Recherches expérimentales sur la maturation in vitro des oocytes de truie et de veau. Ann. Biol. Anim. Bioch. Biophys. 9, 329-349

Fulka J. Jr., Motlík J., Fulka J., Jilek F. (1986) Effect of cycloheximide on nuclear maturation of pig and mouse oocytes. J. Reprod. Fertil. 77, 281-285

Gwatkin R.B.L. \& Andersen O.F. (1976) Hamster oocyte maturation in vitro inhibition by follicular components. Life Sci. 19, 527-536

Hiilensjö T., Batta S.K. \& Schwatz-Kripner A. (1978) Inhibitory effect of human follicular fluid upon the maturation of porcine oocytes in culture. J. Clin. Endocrinol. Metab. 47, 1332-1335

Hillensjö T., Channing C.P., Pomerantz S.H. \& Kipner A.S. (1979) Intrafollicular control of oocyte maturation in the pig. In vitro 15, 32-39

Hillensjö T., Chari S., Magnusson C., Daume E. \& Sturm G. (1981) Inhibitory effect of low molecular weight fraction of human follicular fluid upon rat granulosa cells and oocytes in vitro. In: $\mathrm{Hu}$ man Reproduction (K. Semm \& K. Mettler eds), Excerpta Medica, International Congress Series No. 551, Amsterdam, pp. 458-462

Homa S.T., Mc Gaughey R.W. \& Racowsky C. (1988) Isolated subpopulation of mass-harvested pig oocytes and their characterization by size, incidence of atresia and competence to mature in culture. J. Reprod. Fertil. 82, 81-86

Kubelka M., Motlík J., Fulka J. Jr., Procházka R., Rimkevičová Z. \& Fulka J. (1988) Time sequence of germinal vesicle breakdown in pig oocytes after cycloheximide and p-amidobenzamide block. Gamete Res. 19, 423-431

Liebfried L. \& First N.L. (1980a) Effect of bovine and porcine follicular fluid and granulosa cells on maturation in vitro. Biol. Reprod. 23, 699-704

Liebfried L. \& First N.L. (1980b) Follicular control of meiosis in the porcine oocyte. Biol. Reprod. 23, 705-709

Mattioli M., Galeati G., Bacci M.L. \& Seren E. (1988a) Follicular factors influence oocyte fertilizability by modulating the intercellular coopera- 
tion between cumulus cells and oocyte. Gamete Res. 21, 223-232

Mattioli M., Galeati G. \& Seren E. (1988b) Effect of follicle somatic cells during pig oocyte maturation on egg penetrability and male pronucleus formation. Gamete Res. 20, 177-183

Moor R.M. \& Crosby I.M.(1986) Protein requirements for germinal vesicle breakdown in ovine oocytes. J. Embryol. Exp. Morphol. 94, 207-220

Motlik J. \& Fulka J. (1976) Breakdown of the germinal vesicle in pig oocytes in vivo and in vitro. J. Exp. Zool. 198, 155-162

Naito K., Fukuda Y. \& Toyoda Y. (1988) Effects of porcine follicular fluid on male pronucleus formation in porcine oocytes matured in vitro. Gamete Res. 21, 289-295

Pomerantz S.H. \& Bilello P.A. (1987) Inhibition of progesterone-mediated maturation of oocytes of Xenopus laevis by oocyte maturation inhibitor from pig follicular fluid: development of routine assay for the inhibitor with Xenopus oocytes. Gamete Res. 17, 267-278

Sato E. \& Koide S.S. (1984) A factor from bovine granulosa cells preventing oocyte maturation. Differentiation 26, 59-62

Sato E. \& Koide S.S. (1987) Biochemical transmitters regulating the arrest and resumption of meiosis in oocytes. Int. Rev. Cytol. 106, 1-33

Sato E., Ueno H. \& Koide S.S. (1986) Mouse oocyte maturation modulated by a granulosa cell factor and by heparin and heparin sulphate. Gamete Res. 13, 115-124

Thibault C., Szöllösi D. \& Gérard M. (1987) Mammalian oocyte maturation. Reprod. Nutr. Develop. 27, 865-896

Tsafriri A. (1988) Local nonsteroidal regulators of ovarian function. In : The Physiology of Reproduction (E. Knobil \& J. Neill, eds), Raven Press, New York, pp. 527-565

Tsafriri A. \& Bar-Ami S. (1982) Oocyte maturation inhibitor : a 1981 perspective. In : Intraovarian Control Mechanisms. Advances in Experimental Medicine and Biology (P.C. Channing \& S.J. Segal, eds), Plenum Press, New York, pp. 145-159

Tsafriri A. \& Channing C.P. (1975) An inhibitory influence of granulosa cells and follicular fluid upon porcine meiosis in vitro. Endocrinology 96, 922-927

Tsafriri A., Channing C.P., Pomerantz S.H. \& Lindner H.R. (1977) Inhibition of maturation of isolated rat oocytes by porcine follicular fluid. $J$. Endocrinol. 75, 285-291

Yding Andersen C., Wastergaard L., Byskov A.G., Grinsted J. \& Lauritsen G.L. (1981) Possible regulation of meiosis in the human ovary. In : Proc. III World Congr. in Human Reproduction (K. Semm \& N. Mettler, eds), Excerpta Medica, Amsterdam, pp. 449-452 